\title{
Effect of irrigation and nitrogen levels on forage yield and quality of pearl millet [Pennisetum glaucum (L.) R.Br.]
}

\author{
PANKAJ PAREEK ${ }^{1}$, M.R. PATEL*, H.K. PATEL ${ }^{1}$ AND P.M. PATEL ${ }^{1}$ \\ ${ }^{1}$ Main Forage Research Station (A. A.U.) ANAND (GUJARAT) INDIA
}

\begin{abstract}
An experiment was conducted to study the effect of irrigation and nitrogen on pearl millet during summer 2010 at Anand Agricultural University, Anand. Twelve treatment combinations of four irrigation levels (0.4, 0.6, 0.8 and 1.0 IW: CPE ratio), three levels of nitrogen $\left(80,120\right.$ and $\left.160 \mathrm{~kg} \mathrm{~N} \mathrm{ha}^{-1}\right)$ were tested in split plot design with four replications. The result revealed that the frequent irrigations at 1.0 IW : CPE ratio significantly increased the plant height, tillers per meter row length and leaf : stem ratio and produced significantly the highest green forage, dry matter and crude protein yields and registered the highest net returns. However, lower irrigation level of $0.4 \mathrm{IW}$ : CPE ratio was significantly superior in WUE than $1.0 \mathrm{IW}$ : CPE ratio. Successive increase in nitrogen application increased yield attributes, leaf, stem ratio, crude protein content as well as WUE. Application of $160 \mathrm{~kg} \mathrm{~N}$ ha $^{-1}$ recorded significantly the highest green forage, dry matter and crude protein yields of pearl millet and gave the highest net returns.
\end{abstract}

Key Words : Irrigation, Nitrogen, Forage, Pearl millet

View Point Article : Pareek, Pankaj, Patel, M.R., Patel, H.K. and Patel, P.M. (2015). Effect of irrigation and nitrogen levels on forage yield and quality of pearl millet [Pennisetum glaucum (L.) R.Br.]. Internat. J. agric. Sci., 11 (2) : 264-267.

Article History : Received : 12.12.2014; Revised : 15.05.2015; Accepted : 23.05.2015

\footnotetext{
* Author for correspondence

Department of Agronomy, B.A. College of Agriculture, Anand Agricultural University, ANAND (GUJARAT) INDIA (Email : hirenubi@gmail.com)
} 